\title{
MAKNA CINTA DALAM KUMPULAN PUISI W.S RENDRA
}

\author{
Heni Pujiati \\ Khurothul Firdha Usia \\ Ineda Ayuni Herdianti \\ Program Studi Pendidikan Bahasa dan Sastra Indonesia \\ Universitas Muhammadiyah Malang \\ Hpujiati622@gmail.com
}

\begin{abstract}
Abstrak :
Karya sastra yang berupa puisi dapat menyampaikan pikiran-pikiran dari pengarang itu sendiri. Puisi banyak membahas tentang kehidupan sehari-hari seperti, cinta, sosial, politik, ekonomi dan sebagainya. Penelitian ini bertujuan untuk mengetahui makna cinta menurut W.S Rendra. Penelitian ini menggunakan pendekatan semiotika yang mengacu pada teori Ferdinand de Saussure tentang penanda (signified) dan petanda (signifier). Jenis penelitian ini berupa deskriptif kualitatif dengan metode analisis isi. Sumber data yang digunakan dalam penelitian ini adalah puisi W.S Rendra yang berjudul Telah Satu, Optimisme, Surat Cinta, Nota Bene (Aku Kangen) dan Mata Hitam. Hasil dari penelitian ini adalah mengetahui makna dari setiap puisi W.S Rendra dan mengartikan makna melalui tanda-tanda, simbol dari sebuah kata maupun kalimat. Setiap puisi cinta W.S Rendra memiliki makna cinta yang berbeda-beda tidak selalu berakhir bahagia.
\end{abstract}

\section{Abstract:}

Literary works in the form of poetry can convey the thoughts of the author. Poetry talks about everyday life like love, social, politics, economy, and so on. This study aims to determine the meaning of love according to W.S Rendra. This research using semiotic approach refers to Ferdinand de Saussure theory about signified and signifier. This research type is qualitative descriptive with content analysis method. The data source used in the research is the poem W.S Rendra titled Telah Satu, Optimisme, Surat Cinta, Nota Bene (Aku Kangen), dan Mata Hitam. The result of this study is to know the meaning of each poem W.S Rendra and interpret meaning through the signs, symbols of a word or sentence. Every love poem W.S Rendra has a different meaning of love does not always end up happy.

\section{PENDAHULUAN}

Karya sastra merupakan wujud permainan kata-kata pengarang yang berisi maksud tertentu, yang akan disampaikan kepada penikmat sastra dan masyarakat. Karya sastra adalah wacana yang khas yang di dalam ekspresinya menggunakan bahasa dengan memanfaatkan segala kemungkinan yang tersedia (Sudjiman 1993:7).
Pada dasarnya puisi adalah karya sastra yang ditulis oleh penulis untuk menyampaikan pikiran penulis kepada pembaca, begitu juga dalam menyampaikan informasi melalui imajinasi yang tinggi dan menyampaikan maksud dari puisi yang ditulis oleh penulis. Herman J. Waluyo dalam Muntazir (dalam Muntazir, 2017: 211) menjelaskan bahwa luasnya subyek puisi 
adalah wujud karya sastra yang mengemukakan tentang pikiran dan gagasan pengarang dengan cara imajinatif dan diatur lebih memfokuskan semua kekuatan bahasa dengan memusatkan pada struktur fisik dan struktur batinnya.

Puisi sebagai salah satu jenis karya sastra memiliki susun bahasa yang simbolis dan relatif lebih padat dibandingkan dengan prosa. Pemilihan kata atau diksi dalam puisi sangat ketat. Kehadiran kata-kata dan ungkapan dalam puisi diperhitungkan dari berbagai segi, antara lain; makna, kekuataan citraan, rima, dan jangkauan simboliknya (Pradopo, 2007:121).

Menurut Antonucci (dalam Ariyati dan Nuqul, 2016:29) tahap awal perkembangan dewasa terlihat dari individu yang tidak lepas dari masalah cinta. Cinta tumbuh dari stimulus dan respon dari setiap individu. Cinta diungkapkan melalui banyak hal, cinta ada yang tersirat dan tersurat, dilihat dari bagaimana cara kita mengungkapkan cinta itu sendiri.

Cinta dapat diapresiasikan melalui karya sastra berupa drama, musik, cerpen, puisi dan sebagainya. Cinta dapat dirasakan oleh setiap individu baik remaja, orang tua bahkan anak-anak. Mereka mengenal cinta melalui perasaan yang ada dalam dirinya. Menurut pendapat (Wisnuwardhani, dalam Ariyati dan Fathul
Lubabin Nuqul, 2016: 29) cinta akan selalu menjadi topik yang digandrungi oleh setiap kalangan, baik yang muda ataupun yang tua, terbukti dari drama, teater, puisi, sajak, komik, novel, bahkan gosip tentang cinta.

Pemilihan kumpulan puisi cinta karya W.S Rendra didasarkan pada segi bahasa yang digunakan menarik untuk dikaji lebih jauh. Hal inilah yang mendorong penulis untuk melakukan penelitian tentang bahasa yang digunakan W.S Rendra dalam menyampaikan makna dan pesan cerita untuk mengkaji makna puisi tersebut. Cinta bukanlah hal yang tabu bagi kita para remaja. Banyak yang mengartikan cinta tumbuh melalui hati nurani.

Permasalahan yang diangkat oleh penulis adalah bagaimana makna cinta dalam kumpulan puisi cinta karya W.S Rendra. Tujuan dari penelitian ini adalah untuk mengetahui makna cinta menurut W.S Rendra. Penelitian ini dilakukan karena belum ada yang meneliti mengenai makna cinta dalam puisi-puisi cinta W.S Rendra. Oleh karena itu, penulis melakukan penelitian terkait makna cinta dalam puisi W.S Rendra. Pemilihan kata yang digunakan oleh W.S Rendra berbeda dengan pengarang lainnya, karena W.S Rendra memiliki ciri khas tersendiri dalam mengungkapkan cinta menurutnya ke dalam puisi. 
Pemilihan kata yang digunakan W.S Rendra lebih cenderung memakai katakata yang bersifat konotatif dan denotatif. Selain itu, karakteristik puisi W.S Rendra lainnya berupa karya-karyanya mampu menghipnotis pembaca. Pembaca seolaholah dapat berimajinasi sendiri dengan apa yang digambarkan dalam karya W.SRendra, di antaranya kekhasan bahasa yang terdapat dalam puisi yang berjudul "Surat Cinta", “ Mata Hitam”, “ Nota Bene (kangen)", “Telah Satu”, dan "Optimisme”.

Puisi yang pertama berjudul Telah Satu, menggambarkan tentang kisah sepasang kekasih yang sangat mencintai satu sama lain. Sepasang kekasih ini seakan-akan tidak akan terpisahkan oleh apapun.

Puisi kedua adalah Mata Hitam, menceritakan mengenai seorang lelaki yang merindukan tambatan hatinya. Rindu akibat lama tak melihat sepasang mata yang indah milik kekasihnya.

Puisi ketiga adalah Nota Bene (kangen) adalah salah satu judul puisi W.S Rendra, yang menceritakan perihal keinginan untuk bertemu karena rindu. Pengarang juga menuliskan tentang cinta tidak memandang dari riasan wajah yang dikenakan kekasihnya dan bertahan pada kehidupan.

Puisi keempat adalah Surat cinta menceritakan tentang proses kisah cinta sang pengarang kepada wanita idamannya yang bernama Dik Narti berawal dari mengagumi, mengatakan cinta hingga menikahinya.

Puisi kelima adalah Optimisme menceritakan kisah cinta tidak selalu berjalan mulus tanpa adanya sebuah permasalahan.

Pendekatan yang digunakan dalam penelitian ini adalah pendekatan semiotika. Pendekatan semiotika tentunya tidak terlepas dari makna yang tertera dalam tanda-tanda, karena pendekatan semiotika memandang karya sastra sebagai sistem tanda. Semiotika adalah ilmu atau metode analisis untuk mengkaji tentang tanda (Hoed, 1992: 2 dalam Nurgiyantoro, 2013: 67). Ilmu ini menganggap bahwa fenomena sosial atau masyarakat dan kebudayaan merupakan bentuk dari tandatanda. Dalam semiotika semua sistem serta aturan-aturan yang berkaitan dengan tanda mempunyai arti atau makna.

\section{KAJIAN PUSTAKA}

Menganalisis sebuah karya sastra yang berhubungan erat dengan suatu makna yang terkandung dalam karya tersebut. Menurut Ferdinand de Saussure semiotika adalah tanggapan dan pendapat tentang realitas, disusun oleh kata dan tanda lain yang digunakan dalam konteks sosial (Sobur, dalam Rawung 2013:4). Dapat diartikan bahwa tanda digunakan untuk membentuk persepsi manusia, tidak 
hanya sekedar gambaran dari realitas yang ada.

Ferdinand de Saussure menegaskan bahwa petanda adalah sesuatu yang berkaitan dengan aktivitas mental individu yang menerima suatu penanda. Tanda mengungkapkan ide dan menandakan bahwa dia tidak sejalan dengan interpretasi Platonis atau istilah ide. Ide sebagian kejadian atau peristiwa mental yang menjadi sasaran pikiran manusia (Eco, dalam Rawung 2013:7). Hubungan penanda dan petanda sangat bersangkutan pada aktivitas mental yang dimunculkan oleh setiap individu.

Teori semiotika yang ditemukan oleh Ferdinand de Saussure yang menyatakan bahwa semiotik adalah ilmu yang mengkaji tentang sebagai bagian dari kehidupan. Implisit dalam definisi Saussure adalah kebenaran, bahwa semiotika sangat menyadarkan dirinya pada aturan main atau kode sosial yang berlaku dalam masyarakat, sehingga tanda dapat dipahami maknanya secara kolektif (Lutfillah, 2014:22). Teori yang dikemukakan Saussure menekankan pada tanda yang ada dalam kehidupan masyarakat dan berhubungan dengan masyarakat.

Menurut Saussure (dalam Lutfillah, 2014:11) tanda memiliki dua wujud, yakni Signifer (penanda) dan Signifed (petanda). Signifer adalah ucapan yang bermakna atau tulisan yang bermakna (aspek material), yaitu apa yang disampaikan dan ditulis atau dibaca. Signifed adalah adalah uraian mental, yakni konsep atau pikiran aspek mental dan bahasa. Jadi, Saussure membagi tanda menjadi dua yaitu komponen Signifer (penanda) dan Signifed (petanda), hubungan antar keduanya adalah arbitrer.

Signifer (penanda) adalah suatu entitas yang mengarah pada penanda yang tertulis di sebuah puisi yang berdasarkan penyampaian dari pengarang. Di setiap karangan puisi selalu memiliki penanda untuk menunjukkan khas dari setiap penulis, terutama puisi W.S Rendra.

Signifed (petanda) merupakan suatu wujud atau gambaran mental yang membahas tentang tanda-tanda yang ada dalam tulisan. Petanda (signifed) juga suatu makna yang dapat dilihat jika memaknai suatu karya.

Penggunaan teori semiotika oleh Ferdinand de Saussure dapat membantu dalam menentukan presepsi cinta yang terdapat pada kumpulan puisi cinta W.S Rendra dengan menggunakan Signifer (penanda) dan Signifed (petanda).

\section{METODE}

Penelitian puisi karya W.S Rendra ini menggunakanjenis penelitian kualitatif. Penelitian kualitatif memiliki karakteristik yaitu dengan menyatakan data dalam keadaan yang sewajarnya tanpa adanya 
perubahan dan data yang digunakan bukanlah angka-angka melainkan katakata atau gambaran. Penelitian kualitatif bertujuan untuk menemukan makna cinta dalam kumpulan puisi W.S Rendra.

Pendekatan yang digunakan dalam penelitian ini yaitu menggunakan pendekatan Semiotik. Pendekatan ini sangat tepat digunakan dalam penelitian ini karena pendekatan semiotik menganalisis makna karya sastra melalui tanda-tanda dalam bahasa yang digunakan.

Sumber data yang digunakan berupa kumpulan puisi W.S Rendra yang berjudul Mata Hitam, Surat Cinta, Nota Bene (kangen), Telah Satu, dan Optimisme.Data dalam penelitian ini berupa beberapa kata yang mengandung makna cinta dalam puisi-puisi W.S Rendra dengan memperhatikan penanda (signifed) dan petanda (signifer) yang ada dalam puisipuisinya.

Teknik pengumpulan data yang digunakan dalam penelitian ini ialah teknik studi pustaka atau dokumen. Langkahlangkah yang dapat dilakukan seperti (1) membaca, (2) mengamati, (3) menandai hal-hal penting yang berkaitan dengan objek penelitian, dan (4) mencatat hasil yang telah ditandai dan akan diulas berdasarkan teori pada bagian pembahasan. Memanfaatkan sumbersumber yang tertulis guna untuk mendapatkan data, hal ini biasa disebut dengan teknik pustaka (Subroto, dalam Siswono 2014:60).

Pengkaji menggunakan metode analisis isi. Penyelidikan kali ini bukan hanya menjabarkan temuan yang didapat, namun akan diberikan ulasan atas penemuan yang diperoleh guna memberikan penjelasan dan pemahaman atas hal-hal apa saja yang ditemukan dan dibahas tentang tanda-tanda atau faktafakta yang ada dalam puisi W.S Rendra.

Untuk mengecek keabsahan data, peneliti melakukan triangulasi. Ketiga triangulasi tersebut antara lain: (1) triangulasi teori, (2) triangulasi sumber data, dan (3) triangulasi peneliti. Melalui langkah uji validitas tersebut, peneliti bisa lebih mudah mendapatkan data tentang teori yang cocok sebagai acuan penelitian. Triangulasi sumber data, yaitu teknik menyelaraskan kebenaran data hasil analisis, menggunakan beberapa sumber mengenai penanda dan petanda, metode yaitu deskriptif analisis ini dengan penelitian yang dibauat, juga teori penanda dan petanda Ferdinand de Saussure.

\section{HASILDAN PEMBAHASAN}

Puisi memiliki makna yang sangat dalam ketika benar-benar diketahui secara mendalam. Makna puisi dapat memberikan gambaran keinginan, pengharapan, pengungkapan begitu juga setiap hal yang ingin diungkapkan tidak secara gamblang. Contohnya pada kumpulan puisi cinta W.S 
Rendra menyatakan bagaimana pengungkapan cinta melalui puisi, bagaimana makna cinta yang tak tersampaikan, bagaimana bukti cinta yang diungkapkan melalui makna puisi di dalamnya dsb. Sehingga penulis memilih beberapa puisi W.S Rendra diantaranya ialah puisi "Surat Cinta”, " Mata Hitam”, “ Nota Bene (kangen)","Telah Satu”, dan "Optimisme". Berikut pemaknaan puisi cinta W.S Rendra dengan menggunakan pendekatan semiotik teori Ferdinand de Saussure

\section{Puisi Telah Satu}

\section{Bait I}

Aspek Penanda:

Gelisahmu adalah gelisahku.

Berjalanlah kita bergandengan

dalam hidup yang nyata

dan kita cintai.

Aspek Petanda:

Pada kata bergandengan memiliki makna saling terikat, yang berarti mereka tidak bisa terpisahkan. Walaupun setiap orang belum tentu bergandengan dengan kekasih, tetapi dalam bait di atas disebutkan bahwa mereka saling mencintai. Dalam bait di atas juga menunjukkan bahwa setiap suka maupun duka sepasang kekasih akan tetap bersama dalam kehidupan nyata.

Menurut Verhaar (dalam Hidayat, 2014:252) ada ide mengungkapkan makna ada informasi dan maksud. Informasi dan maksud merupakan suatu hal yang luarujaran. Perbedaan diantaranya yakni informasi merupakan suatu hal yang luarujaran dapat dilihat dari topik-topik yang dibicarakan, sedangkan maksud merupakan suatu hal yang dilihat dari sisi pembicaranya.

Menjalani hidup seorang diri berbeda saat menjalani hidup dengan pasangan. Hal ini dikarenakan prinsip kehidupan mengalami perubahan. Perbedaan prinsip terlihat dari saat hidup sendiri tidak ada orang yang dikhawatirkan atau orang yang membuat kita cemas dan tak ada yang dapat digandeng, hal tersebut berbeda dengan saat hidup bersama pasangan atau kekasih kita, salah satu dari pasangan akan merasakan kekhawatiran atau kecemasan akan suatu hal pada pasangannya dan saat mempunyai pasangan, kita dapat menggandeng kekasih kita.

Bait II

Aspek Penanda:

Lama kita saling bertatap mata

Dan makin mengerti

Tak lagi bisa dipisahkan

Aspek Petanda

Pada kata bertatap mata memiliki makna saling melihat, yang berarti mereka memperhatikan satu sama lain. Dalam bait di atas menunjukkan bahwa mereka sudah saling mengenal, saling mengetahui satu sama lain dan tidak dapat dipisahkan. 
Berkomunikasi tak hanya saling mengeluarkan ucapan atau kata-kata, tetapi juga dapat melalui bertatapan mata. Seseorang dapat mengutarakan atau mengungkapkan perasaannya dengan menatap satu sama lain.

Dari kutipan pada bait di atas menunjukkan pengarang sedang melakukan interaksi dengan pasangannya melalui bertatap mata. Mereka berkomunikasi dengan cara itu, sebab itu mereka mengetahui bahwa tidak lagi dipisahkan atau terpisah.

Munculnya makna dikarenakan adanya keterkaitan antara penanda atau signifier dengan yang ditandai, petanda atau signified, tetapi secara kesepakatan harus disahkan oleh segenap pendukung konsep makna tersebut (Triandjojo, 2008:53). Jadi, untuk melahirkan makna harus melalui persetujuan secara konvensional agar hasil yang dicapai dapat dipertanggungjawabkan.

\section{Bait III}

\section{Aspek Penanda}

Engkau adalah peniti

Yang telah disematkan.

Aku adalah kapal

Yang telah berlabuh dan ditambatkan

Aspek Petanda:

Pada bait di atas menunjukkan sepasang kekasih yang saling melengkapi. Terlihat dari kata disematkan dan ditambatkan yang berarti mereka saling membutuhkan.

Dalam penanda dan petanda di atas, menunjukkan saling terhubungnya antar kedua aspek itu. Kedua bagian sangat berpadu dan tidak dapat dipisahkan satu sama lain. Gabungan dari suatu citra bunyi dan konsep yang setelah itu menghasilkan tanda (Mutmainah, 2012:65)

Bait IV

Aspek Penanda:

Kita berdua adalah lava

Yang tak bisa diuraikan

Aspek Petanda:

Pada kata lava memiliki makna dua insan yang sedang dimabuk asmara. Dapat dikatakan bahwa cinta mereka sedang membara. Dalam bait tersebut menunjukkan bahwa mereka tidak dapat terpisahkan.

Secara konvensional lava adalah bagian dari gunung berapi dan sesuatu yang tidak dapat diuraikan. Berbeda halnya dengan bait di atas, yang menunjukkan bahwa dua insan yang sedang jatuh cinta itu tidak dapat dipisahkan dengan cara apapun.

Menurut Tinarbuko (dalam Nurhidayati, 2017:270) tanda dalam kehidupan sehari-hari dapat berupa tanda gerak ataupun isyarat. Hal yang dimaksudkan adalah seperti anggukan 
kepala atau mengangkat alis dapat diartikan sebagai setuju.

\section{Puisi Optimisme}

Bait I

Aspek Penanda:

Cinta kita berdua

Adalah istana dan porselen.

Angin telah membawa kedamaian

Membelitkan kita dalam pelukan

Aspek Petanda:

Pada bait ini terdapat kata istana dan porselen, hal itu menunjukkan suatu kemewahan. Cinta dari sepasang kekasih itu merupakan cinta yang sederhana. Cinta yang penuh dengan kemewahan tetapi tetap menjunjung tinggi kesederhanaan mereka.

Menurut Triandjojo (2008, 50) penanda dan petanda dapat dibedakan tetapi ketika memperagakannya tidak dapat dipisahkan, keduanya saling tergantung dan saling menyatu. Hal tersebut dapat dilihat pada bait di atas, yang menunjukkan bahwa cinta mereka sederhana walaupun penuh dengan kemewahan disekitarnya.

\section{Surat Cinta}

Aspek penanda

Kutulis surat ini

kala hujan gerimis

bagai bunyi tambur mainan

anak-anak peri dunia yang gaib.

Dan angin mendesah

mengeluh dan mendesah

Wahai, Dik Narti, aku cinta kepadamu!
Aspek petanda

Pada bait ini terdapat kata bunyi tambur mainan dan angin mendesah, hal itu menunjukkan suatu pengungkapan. Perasaan yang dipendam yang akhirnya diungkapkan kepada Dik Narti bahwa penyair mencintai Dik Narti. Dalam tanda terungkap citra bunyi atau konsep sebagai dua komponen yang tak terpisahkan(Hidayat, 2014: 245).

Aspek pananda

Kutulis surat ini kala langit menangis dan dua ekor belibis bercintaan dalam kolam bagai dua anak nakal jenaka dan manis mengibaskan ekor serta menggetarkan bulu-bulunya. Wahai, Dik Narti, kupinang kau menjadi istriku!

Aspek petanda

Menunjukkan bahwa penyair ingin menyampaikan keinginan untuk meminang dek Narti pada kalimat kupinang kau.Makna sebagai hubungan antara bahasa dengan dunia luar yang telah disepakati bersama oleh pemakai bahasa sehingga dapat saling dimengerti (cf.Grice dan Fiske dalam Hidayat, 2014:246) . pemakaian bahasa memiliki makna yang sudah ditentukan, dengan menggunakan makna sebenarnya ataukah dengan makna yang tidak sebenarnya pada bait-bait tertentu, itu merupakan kesepakatan antar penyair. 
Aspek penanda

Kaki-kaki hujan yang runcing menyentuhkan ujungnya di bumi.

Kaki-kaki cinta yang tegas

bagai logam berat gemerlapan

menempuh ke muka

dan tak'kan kunjung diundurkan.

Aspek petanda

Bait ini terdapat kata diundurkan menyatakan bahwa ketika seseorang sudah pada keputusanya maka sampai kapanpun ia akan tetap pada keputusanya tanpa goyah sedikitpun. Sifat ambigu dan penuh ekspresi menyebabkan sastra cenderung mempengaruhi dan mengubah sikap pembaca (Wellek dan Warren, dalam Hidayat,2014 : 247). Pemaikaian makna konotasi seringkali mempengaruhi pembaca dalam pemaknaan, sehingga ada titik pasti dimana pemakaian bahasa menggunkan makna yang sebenarnya.

Aspek penanda

Selusin malaikat telah turun di kala hujan gerimis. Di muka kaca jendela mereka berkaca dan mencuci rambutnya untuk ke pesta.

Wahai, Dik Narti, dengan pakaian pengantin yang anggun bung-bunga serta keris keramat aku ingin membimbingmu ke altar untuk dikawinkan.

Aspek petanda
Pada bait ini menyatakan angan-angan penyair ketika pernikahan berlangsung di pelaminan, dapat dilihat pada kata altar. Konsep mental yang terkait dengan petanda dapat dikaitkan dengan ara ikonik ( Agustini dan Novando, 2015: 8). pemakaian ikonik dalam puisi ini menggambarkan sebuah pernikahan antara penyair dan Dik Narti dalam sebuah ikatan sakral yaitu perkawinan.

Aspek penanda

Aku melamarmu.

Kau tahu dari dulu:

tiada lebih buruk

dan tiada lebih baik

daripada yang lain

penyair dari kehidupan sehari-hari, orang yang bermula dari kata

kata yang bermula dari

kehidupan, pikir dan rasa.

Semangat kehidupan yang kuat bagai berjuta-juta jarum alit menusuki kulit langit:

kantong rejeki dan restu wingit.

Lalu tumpahlah gerimis.

Angin dan cinta mendesah dalam gerimis.

Semangat cintaku yang kuat

bagai seribu tangan gaib

menyebarkan seribu jaring

menyergap hatimu

yang selalu tersenyum padaku.

Aspek petanda

Pada kalimat seribu tangan gaib menggambarkan usaha keras tanpa ragu, melakukan segala rayuan, mencari restu dan kepercayaan yang berakhir dengan suatu keberhasilan.Mendeskripsikan atau mengkaji makna kalimat adalah ungkapan 
dalam bahasa tertentu. (John Lyons, 2001: 138-9). Dalam pemakaian makna tertentu, menghasilkan suatu persepsi yang berbeda pula pada setiap baitnya, sehingga tidak digambarkan secara langsung apa yang sebenarnya terjadi..

\section{Aspek penanda}

Engkau adalah putri duyung tawananku.

Putri duyung dengan suara merdu lembut

bagai angin laut, mendesahlah bagiku!

Angin mendesah selalu mendesah dengan ratapnya yang merdu.

Engkau adalah putri duyung tergolek lemas mengejap-ngejapkan matanya yang indah

dalam jaringku.

Wahai, Putri Duyung, aku menjaringmu aku melamarmu

Aspek petanda

Pada bait ini ada kata putri duyung yang menggambarkan pesona Dik Narti. Konsep mental yang terkait dengan petanda dapat dikaitkan dengan ara ikonik (Agustini dan Novando, 2015: 8). Pesona Dik Narti digambarkan mulai dengan keindahan dirinya, suaranya dan pandangan matanya dijelaskan secara gamblang.

Aspek penanda

Kutulis surat ini

kala hujan gerimis

karena langit gadis manja dan manis menangis minta mainan.

Dua anak lelaki nakal bersenda gurau dalam selokan dan langit iri melihatnya.

Wahai, Dik Narti, kuingin dikau menjadi ibu anak-anakku!

(Empat Kumpulan Sajak, 1969).

Aspek petanda

Pada bait ini menyatakan bahwa pengharapan penyair agar selamanya bersama dek narti bersanding dipelaminan dan memiliki anak, dapat dilihat dari kalimat ku ingin kau menjadi ibu dari anak-anakku. Pemaknaan antara makna kata dengan wujud yang dimaknai selalu memiliki hubungan yang hakiki (Fiske dalam Hidayat,2014: 246). Pada bait di atas menggambarkan bagaimana hubungan antara makna kata dan wujud yang dimaknai sama-sama memiliki tujuan yang sama. Antara bait dengan baik juga memiliki hubungan terkait satu sama lain, sehingga dapat diketahui makna dari setiap baitnya.

\section{Nota bene aku kangen}

Bait I

Aspek Penanda

Lunglai ganas karena bahagia dan sedih,

Indah dan gigih cinta kita di dunia yang fana

Nyawamu dan nyawaku dijodohkan langit,

Dan anak kita akan lahir di cakrawala. 
Aspek Petanda

Pada bait ini, menceritakan bahwa cinta mereka menandakan kebahagiaan dan kesedihan yang tidak nyata. Keinginan untuk bertemu akan tetapi tidak kesampaian.

Pemaparan bait pertama adalah bisa di lihat lirik tersebut, pengarang melawan kelemahannya karena bahagia dan sedih. Namun dalam bait tersebut menjelaskan cinta di dunia tidaklah nyata, dapat hilang seiring berjalannya waktu dan cinta mereka akan menyatu dalam langit atau surga bukanlah di dunia, sedangkan anak mereka lahir akan dari bintang-bintang. Hal ini menunjukkan bahwa segigih apapun cinta di dunia dapat rusak dan hilang.

Penggantian arti yakni untuk menemukan makna pada umumnya terjadi dalam teks yang menggunakan kata-kata (diksi) kiasan sehinga suatu kata memiliki arti yang lain, sedangkan penyimpangan arti terjadi bila dalam sajak ada ambiguitas, kontradiksi, ataupun nonsense (Pradopo, 2005:212-213).

\section{Bait II}

Aspek Penanda

Adapun mata kita akan terus bertatapan

Hingga berabad-abad lamanya.

Juwitaku yang cakap

Meskipun tanpa dandanan

Untukmu hidupku terbuka.

Warna-warna kehidupan berpendarpendar menakjubkan
Isyarat-isyarat getaran ajaib menggerakkan penaku.

Tanpa sekejap pun luput dari kenangan padamu

$\mathrm{Aku}$ bergerak menulis pamplet, mempertahankan kehidupan.

\section{Aspek Petanda}

Bait ini menyatakan bahwa wanita itu sebagai inspirasi bagi penyair dengan apa adanya, dan tetap melihatnya dan melanjutkan kehidupan dalam angan-angan semata karena keinginan untuk bertemu tidak dapat tercapai.

Pemaparan bait kedua adalah bisa di lihat bahwa dalam lirik tersebut pengarang bercerita tentang wanita yang ia cintainya. Ia rela selama bertahun-tahun hingga berabad-abad untuk tetap bersama wanitanya. Kehidupannya dengan wanita itu sangat bercahaya dan berwarna-warni. Pengarang juga bercerita bahwa ia tidak akan melupakan sesikitpun kenangannya bersama wanita tersebut. Hal ini menunjukkan bahwa pengarang akan terus berjuang dan mempertahankan kehidupannya serta cinta dia bersama wanita itu. Mendeskripsikan atau mengkaji makna kalimat adalah ungkapan dalam bahasa tertentu. (John Lyons, 2001: 138-9)

\section{Mata Hitam}




\section{Bait I}

Aspek Penanda

Dua mata hitam

Adalah mata hati yang biru

Dua mata hitam

Sangat kenal bahasa rindu

Rindu bukanlah milik perempuan melulu

Dua keduanya sama tahu, dan keduanya tanpa malu

\section{Aspek Petanda}

Pada bait ini, bercerita mengenai suatu gambaran tentang sebuah rasa rindu terpendam yang dituangkan oleh seorang laki-laki terhadap seorang wanita pujaan hatinya yang juga rindu padanya. Akan tetapi, sang wanita malu untuk mengatakannya kepada sang lelaki. Begitu juga sang lelaki yang juga malu mengungkapkan rasa rindunya.

Pemaparan bait pertama adalah bisa di lihat dalam lirik tersebut pengarang bercerita bahwa yang dimaksud dua mata hitam adalah sepasang mata kita. Sepasang mata sangatlah mengenal bahasa rindu yang terpancar oleh gerak gerik tubuh. Seorang lelaki merindukan pasangannya tetapi ia malu untuk mengungkapkan sebaliknya perempuan juga malu untuk menunjukkan bahwa dia rindu, meskipun mereka berdua saling mengetahui. Hal ini menunjukkan bahwa rindu bukanlah milik perempuan tetapi lelaki juga bisa merindukan sosok yang ia cintai meskipun mereka sama-sama tahu rindu tetapi malu untuk mengungkapkannya. Sayuti (1985: 1) mengungkapkan puisi merupakan hasil kreativitas manusia yang diwujudkan lewat susunan kata yang mempunyai makna.

\section{Bait II}

Aspek Penanda

Dua mata hitam

Terbenam di daging yang wangi

Kecantikan tanpa sutra, tanpa pelangi

Aspek Petanda

Pada bait ini, menunjukkan bahwa wanita tersebut memiliki kecantikan yang alami tanpa adanya polesan dandanan. Meskipun tanpa adanya polesan kecantikannya tetap terpancar. Pemaparan bait kedua adalah bisa di lihat dalam lirik tersebut pengarang bercerita bahwa sepasang mata masuk kedalam tubuh wanita tersebut yang harum dan kecantikan wanita tersebut sangat rupawan. Hal ini menunjukkan bahwa wanita itu memiliki kecantikan yang alami.

\section{Bait III}

Aspek Penanda

Dua mata hitam

Adalah rumah yang temaram

Secangkir kopi sore hari

Dan kenangan yang terpendam

Aspek Petanda

Pada bait ini, menunujukkan bahwa pengarang sedang mengingat kenangan bersama sang kekasih. Tetapi kenangan tersebut hanya dapat dipendamnya. 
Pemaparan bait ketiga adalah bisa di lihat dalam lirik tersebut pengarang bercerita bahwa sepasang mata adalah tempat ia kembalinya segala aktivitas yang terjadi atau rumah yang akan ia tuju setelah menjalankan rutinitas. Dalam kalimat secangkir kopi sore hari pengarang bercerita secangkir kopi akan mengerti keadaannya yang terjadi dan kenangan yang tersimpan di dalam hati. Hal ini menunjukkan bahwa pengarang sedang mengingat kenangannya bersama sang kekasih di sore hari.

Bagian-bagian itu hanya bermakna dalam rangka keseluruhan tadi. Jadi keseluruhan yang memberikan makna terhadap suatu bagian, individuasi adalah bagian-bagian dari keseluruhan. (Oemar Hamalik. 1998:83)

\section{KESIMPULAN}

Dari hasil penelitian, penulis menemukan makna dalam kumpulan puisi karya W.S Rendra, yaitu yang berjudul "MataHitam", "Surat Cinta", "Nota Bene aku kangen", "Telah Satu”, dan "Optimisme".

Penelitian yang dilakukan oleh penulis menghasilkan sebuah makna dengan menggunakan pendekatan semiotik. Adapun pendekatan semiotik merupakan pendekatan yang mengartikan makna melalui tanda-tanda dan simbol dari sebuah kata maupun kalimat..
Penelitian dilakukan pada suatu pilihan kata yang digunakan W.S Rendra dalam kumpulan puisinya. Secara umum puisi tersebut mengungkapkan gambaran perasaan W.S Rendra yang mendalam mengenai hal yang dilihatnya. Dalam setiap judul puisi W.S Rendra memiliki makna kias dan makna konotasi. Diksi yang digunakan oleh W.S Rendra menggunakan kata metafora yang bersimbolik dengan pendeskripsian dari apa yang dilihat oleh W.S Rendra berupa petanda(Signifed) dan penanda (Signifer).

Pada puisi yang berjudul Mata Hitam memiliki makna atau gambaran tentang sebuah rasa rindu yang terpendam yang di tuangkan oleh seorang laki-laki terhadap seorang wanita pujaan hatinya yang juga rindu kepadanya, akan tetapi sang wanita malu untuk mengatakannya kepada sang lelaki, begitu juga sang lelaki yang juga malu untuk mengungkapkan rasa rindunya kepada sangwanita.

Pada puisi Surat Cinta artinya memiliki kemungkinan kata yang lebih dari satu. Selain itu pemilihan diksi terlihat romantis yang mampu memberikan efek keindahan bagi pembaca. Pemilihan diksi yang romantis tersebut sesuai dengan tema puisi ini, yaitu mengenai perjalanan kisah cinta sang penyair (Rendra) dengan wanita pujaannya (Dik Narti).

Pada puisi Nota Bene aku kangen sebagaimana kita ketahui bahwa kata 
kangen bersinonim dengan kata Rindu yang artinya ingin sekali bertemu atau keinginan yang kuat untuk bertemu dan cinta yang dapat diartikan Suka sekali, dari hal tersebut dapat disimpulkan bahwa dalam puisi ini Ws Rendra Menceritakan Bagaimana dia merasa kangen kepada seorang yang sangat dicintainya menggambarkan apa yang dia rasakan.

Pada puisi Telah Satu mempunyai makna yakni bahwa setiap insan akan dipertemukan satu sama lain, dan tidak dapat dipisahkan. Hal ini dikarenakan pasangan tersebut saling membahagiakan dan saling membutuhkan.

Puisi yang berjudul optimis memiliki makna bahwa hidup yang mereka jalani penuh dengan kebahagiaan dan lika-liku kehidupan.

\section{DAFTAR PUSTAKA}

Agustini dan Novando Andria Purwadi.

\section{Pemaknaan Iklan Serial Rokok}

Djarum Super Analisis Semiotika

Ferdinand de Saussure. Jurnal IPB.

Ariyati, Risky Ananda dan Fathul Lubabi

Nuqul. 2016. Gaya Cinta (Love Style)

Mahasiswa. Volume 13, No. 2 Jurnal

Psikoislamika: Universitas Islam Negeri

Maulana Malik Ibrahim Malang.

Hidayat, Rahmat. 2014. Analisis Semiotika

Makna Motivasi Pada Lirik Lagu

"Laskar Pelangi” Karya Nidji. Volume

2, No. 1 Universitas Mulawarman: ejournal
John Lyons, 2001, Semantics Vol. 1.

Cambridge: Cambridge University Press

Lestari, Emi.2013. Analisis Semiotika

Dalam Antologi Warisan Geguritan

Macapat Karya Suwardi. Volume 02,

No.03. Universitas Muhammadiyah

Purworejo: Jurnal Program Stusi

Pendidikan Bahasa dan Sastra Jawa.

Lutfillah, A Aminnul. 2014. Analisis

Semiotik Model Ferdinand De Saussure

pada Iklan “ARB”. Jurnal Skripsi: UIN

Sunan Ampel Surabaya.

Muntazir. 2017. Struktur Fisik dan

Struktur Batin Pada Puisi Tuhan, Aku

Cinta Padamu Karya WS.Rendra. Jurnal

Pesona, Volume 3 No. 2.

Mutmainah, Andi. 2012. Konstruksi

Realitas Kaum Perempuan Dalam Film

7 Hati 7 Cinta 7 Wanita (Analisis

Semiotika Film). Jurnal skripsi:

Universitas Hasanuddin.

Nurhidayati, Ana. 2017. Nasionalisme

dalam Film Habibie Ainun. Universitas

Mulawarman : e-Journal Ilmu

Komunikasi.

Oemar Hamalik. 1998. Mengajar Asas

Metode Teknik. Bandung: Pustaka

Martina

Pradopo, Rachmad Djoko. 2005.

Pengkajian Puisi. Yogyakarta: Gadjah

Mada University Press.

Rawung, Lidya Ivana. 2013. Analisis

Semiotika Pada Film Laskar Pelangi. 
Volume 1, No. 1 Hal 4\&7. Jurnal Acta

Diurna: Universitas Sam Ratulangi.

Sayuti, A. Suminto. 1985. Puisi dan

Pengajarannya. Yogyakarta: FBS IKIP

Yogyakarta.

Siswono.2014. Teori dan Praktek.

Yogyakarta: Deepublish, September.

Sudjiman, Panuti. 1993. Bunga Rampai

Stilistika. Jakarta: Grafiti.

Triandjojo, Indriani. 2008. Semiotika Iklan

Mobil Di Media Cetak Indonesia.

Universitas Diponegoro: Semarang.

Wellek, Rene dan Austin Warren. 1989.

Teori Kesusastraan. (Terj. Melani

Budianta). Jakarta: Gramedia. 